\title{
High school students' proficiency and confidence levels in displaying their understanding of basic electrolysis concepts
}

Ding Teng Sia, David F. Treagust \& A. L. Chandrasegaran

Science and Mathematics Education Centre, Curtin University, Perth, Australia

\begin{abstract}
This study was conducted with 330 Form 4 (grade 10) students (aged 15 - 16 years) who were involved in a course of instruction on electrolysis concepts. The main purpose of this study was to (1) to assess high school chemistry students' understanding of 19 major principles of electrolysis using a recently developed two-tier multiple-choice diagnostic instrument, the Electrolysis Diagnostic Instrument, EDI, and (2) to assess students' confidence levels in displaying their knowledge and understanding of these electrolysis concepts. Analysis of students' responses to the EDI showed that they displayed very limited understanding of the electrolytic processes involving molten compounds and aqueous solutions of compounds, with a mean score of 6.82 (out of a possible maximum of 17). Students were found to possess content knowledge about several electrolysis processes but did not provide suitable explanations for the changes that had occurred, with less than $45 \%$ of students displaying scientifically acceptable understandings about electrolysis. In addition, students displayed limited confidence about making the correct selections for the items; yet, in 16 of the 17 items the percentage of students who were confident that they had selected the correct answer to an item was higher than the actual percentage of students who correctly answered the corresponding item. The findings suggest several implications for classroom instruction on the electrolysis topic that need to be addressed in order to facilitate better understanding by students of electrolysis concepts.
\end{abstract}




\section{Introduction}

Chemistry is one of several subjects that high school students in Malaysia study over a period of two years in Forms 4 and 5 (grades 10 and 11) in preparation for the Malaysian Certificate of Education Examination. This study involved Form 4 (grade 10) students who commenced learning chemistry in addition to biology, physics, and mathematics subjects that were all taught in English at the time of conducting the research (although instruction in all other subjects was in the national language).

Research continues to investigate students' understanding of electrochemistry concepts (Schmidt, Marohn \& Harrison, 2007) and reviews of past work have been documented in the extant research literature (for example by De Jong \& Treagust, 2002). Despite the scientifically inappropriate conceptions held by students that have been identified in these studies, there is no record of any study that deals purely with electrolysis concepts. Although it is good for students to know about electrochemistry in general, the Malaysian chemistry syllabus places great emphasis on electrolytic processes that occur during electrolysis. In addition, there is no convenient-to-use instrument on electrolysis that is available for use by teachers to assess students' understanding of electrolytic concepts. Two-tier multiple-choice diagnostic tests are convenient to administer and easy to mark, and hence serve as useful diagnostic and formative assessment tools in classroom instruction (Treagust, 1995). Although instruments consisting of two-tier items have been developed in several chemistry topics over the past two decades or so (Treagust \& Chandrasegaran, 2007), no similar assessment instrument on electrolysis has been documented in the science education research literature. Several studies have documented the development and use of diagnostic instruments on electrochemistry involving both electrochemical cells as well as electrolytic cells (for example, Acar \& Tarhan, 2007; Rahayu, Treagust, Chandrasegaran, Kita \& Ibnu, 2011), but no known studies have 
focused purely on the development of a two-tier multiple-choice diagnostic test involving electrolysis only. As a result, the previous studies referred to have only been able to address limited aspects of electrolysis because these studies involved electrolytic and electrochemical cells as well. The instruments that were used in these studies were therefore of limited relevance as the course content on electrolysis is quite extensive. In order to fill this void we developed a two-tier multiple-choice diagnostic instrument on electrolysis concepts, the Electrolysis Diagnostic Instrument (EDI), consisting of 17 items (Sia, 2010). Furthermore, despite being convenient to administer and easy to mark, the development of two-tier multiple-choice items involves a series of elaborate timeconsuming stages, 10 steps in all (Treagust, 1988, 2005), that includes soliciting students' responses to open-ended questions and justifications for selection of responses to multiple-choice items (see Figure 1).

The main purpose of this study was to assess high school students' understandings of basic electrolysis concepts following instruction, as well as to assess their level of confidence in supporting their understandings. The information collected in this manner will provide teachers and curriculum writers clearer insight into students' understanding of basic electrolysis concepts so that they will be able to develop appropriate teaching strategies and materials to help students better understand these concepts. Knowledge of students' confidence levels when responding to the questions would provide teachers with information on the efficacy of the classroom instruction (in addition to students' performance) that had taken place.

\section{Theoretical background}

Students bring to their science classes, pre-instructional conceptions that could interfere with their understanding of new concepts that are taught (Duit, 2009). Students find 
electrochemistry difficult to master because 'they cannot observe or imagine what happens in the microscopic level in an electrochemical reaction' (Yochum \& Luoma, 1995, p. 55). Inappropriate understandings of electrolysis concepts that are held by students have been widely reported in several studies in the research literature (De Jong \& Treagust, 2002; Schmidt, et al., 2007). Often these conceptions are deeply ingrained in students' cognitive structures and are difficult to change (Duit \& Treagust, 1998; Tytler, 2002).

In addition, there is a tendency for students to rote learn facts and principles related to a concept without clear understanding of the concept. In such instances students are unable to apply their understanding in a different context that involves the same concept. Ausubel (1968) contrasted meaningful learning with rote learning. The learner must want to learn meaningfully and must possess the prior knowledge relating to the concept. This is important because it links students' preinstructional conceptions to subject-matter knowledge in order to achieve meaningful learning (Ausubel, 1968; Jung, 1993; Tytler, 2002).

As a result of students not being able to learn science concepts meaningfully, i.e. with understanding, it is not surprising that several alternative conceptions about electrolysis concepts have been identified. Garnett and Treagust (1992a, 1992b) for example, have reported scientifically inappropriate understandings about the electrodes in electrolytic cells: the anode is negatively charged and so attracts cations, while the cathode is positively charged and thus attracts anions. In another study by Sanger and Greenbowe (1997) students have suggested that when identical electrodes are used in electrolysis the same reactions would occur at both the electrodes. Further evidence for the incidence of students' alternative conceptions in electrolysis has been identified in a study by Acar and Tarhan (2007). In their study on electrochemistry involving Form 4 (grade 10) students, they have identified several alternative conceptions about electrolysis in particular that were displayed by the students. These included: (1) The 
polarity of the terminals of the applied voltage has no effect on the site of the anode and cathode; (2) Water does not affect the products of the electrolysis of aqueous solutions; (3) The products of electrolysis of a molten salt and its aqueous solution are the same; (4) When identical electrodes are used in electrolysis the products are the same at both electrodes.

Other factors that influence students' success in learning are their beliefs about the nature of science (Pintrich, Marx, \& Boyle, 1993) as well as students' attitudes towards their learning environment (Duit \& Treagust, 2003; Fraser, Giddings, \& McRobbie, 1993). However, how students' confidence in their knowledge is related to their understanding of particular science concepts in an area has been researched only to a limited extent (Bowen \& Roth, 1999). In an exploratory study, Bowen and Roth found that the confidence high school students had in their own knowledge when answering test questions improved with modeling and encouragement by relatives. Students who were overconfident in their answers suggested that they probably did not re-examine the material that they were studying or reflecting upon, something that all teachers want their students to do. It is likely that students would respond very positively about their confidence in answering questions merely to please their teachers to show them that they have understood all that was taught. However, if the intention for soliciting their confidence levels is made very clear at the outset, we do not believe that students would respond in this manner as by doing so it would only be to their detriment; their teachers would then not see the need to provide in-depth remedial support to the students who have not thoroughly grasped the concepts.

In a study involving a test to assess 8th grade Taiwanese students' knowledge about acids and bases, girls were found to score higher marks than boys, were more confident in their knowledge and were more open about expressing different levels of confidence in the test items (Jack, Liu, Chiu \& Tsai, 2011). 
As mentioned previously, the development of two-tier multiple-choice diagnostic instruments involves a series of complex and time-consuming stages. Briefly, some of the stages involve: (1) delineating the boundaries of the concept involved by listing the propositional content knowledge that students are required to know about the particular concept; (2) developing the first tier of the multiple-choice items based on known alternative conceptions documented in the research literature and from experiences of teachers; (3) administration of the items to students requiring a justification for the choice of response; (4) analyzing the justifications to identify possible alternative conceptions; and (5) developing the second tier of the two-tier items incorporating students' alternative conceptions and the scientifically correct justification. The complete process incorporating several steps in the development of the 17 two-tier multiple-choice items (see Figure 1) took us about 14 weeks. As a result, the items that were developed were rich in information about students' inappropriate scientific understandings about electrolysis concepts and so served as convenient and readily available tools to use in classroom instruction to elicit students' own understandings about electrolysis concepts.

In view of the commonly-held alternative conceptions about electrolysis that have been identified in previous studies we saw the need for the development of a convenient-to-use instrument that could be of assistance to teachers in order to assess students' understanding of electrolysis concepts. Limiting the items to involve only electrolytic processes is relevant as the Malaysian School Certificate chemistry syllabus does not include the study of galvanic cells. 


\section{Purpose and significance of the study}

The main purpose of this study was to (1) to assess Form 4 (grade 10) chemistry students' (15 to 16 years old) understanding of the basic concepts of electrolysis using a two-tier multiple-choice diagnostic instrument (the EDI), and (2) to assess students' confidence levels in displaying their knowledge and understanding of electrolysis concepts. This study would be of interest to high school teachers as the focus is on enabling them to first assess understanding of the basic concepts of electrolysis instead of introducing cognitive overload in students by requiring them to consider both electrolytic and galvanic cells at the same time. As has been mentioned previously, the Malaysian syllabus places greater emphasis on electrolysis concepts at the Form 4 (grade 10) level; galvanic cells are only introduced in the Higher School Certificate (HSC) syllabus in grades $12 \& 13$. Based on the experiences of the first and third authors in teaching chemistry to Malaysian students in years $10-13$, the teaching of electrolysis first at the MCE level and galvanic cells later at the HSC level is advantageous; students at the HSC level are better able to understand the differences between the two processes, the working of an electrolytic cell as involving the effect of an electric current on an electrolyte while in the galvanic cell an electrolyte is used to produce an electric current. Hence, there is a need for developing a convenient instrument to assess students' understanding of electrolysis concepts only.

The study was guided by three research questions as stated below.

(1) How proficient are Form 4 (grade 10) students in understanding the concepts related to the electrolysis of molten compounds and aqueous solutions of compounds?

(2) How consistent are Form 4 (grade 10) students in displaying understanding of the basic principles related to the electrolysis of molten compounds and aqueous solutions of compounds in different contexts? 
(3) How confident are Form 4 (grade 10) students in responding to the 17 items in the EDI?

This study is significant because apart from merely assessing students' understanding of particular science concepts by identifying alternative conceptions that are held by students, the study goes a step further by assessing consistency in students' understanding of various electrolysis concepts in different contexts. The findings of this study, particularly with respect to consistency in students' understanding of electrolysis concepts, will enable comparisons to be made internationally as this topic is an essential component of most high school chemistry curricula.

\section{Research methodology}

\section{Research design and sample}

The study used a mixed quantitative-qualitative method (Merriam, 1998), involving 330 Form 4 (grade 10) students (aged 15 - 16 years) from 11 classes in three high schools in Kuching, Malaysia. The students and teachers involved in the study were convenience samples as the first author was previously a chemistry teacher in Kuching and the six teachers who taught the 11 classes were known to her. Quantitative data was in the form of students' achievement scores on the pilot and final versions of the EDI; qualitative data were obtained through analysis of students' written justifications for selecting particular options from the original multiple-choice items. The chemistry classes were taught by six teachers who had at least three years experience teaching the subject. Class sizes in the three schools (referred to as Schools X, Y and Z) ranged from 14 41 students with an average of 30 students per class.

\section{Syllabus and teaching program}

The teaching program on electrolysis was designed based on the chemistry syllabus developed by the Curriculum Development Division (Malaysian Ministry of Education, 
2008). An extract from the chemistry syllabus pertaining to the electrolysis topic is listed below:

- The meaning of electrolyte, and electrical conductivity.

- Electrolysis of molten compounds, aqueous solutions.

- Identification of cations and anions, describing the electrolytic process, writing half equations for the discharge of ions at anode and cathode, and predicting the products from the electrolysis of other molten compounds or aqueous solutions.

- Factors determining selective discharge of ions at electrodes based on position of ions in electrochemical series, concentration of ions in a solution, types of electrodes.

- Electrolysis in industry, the purification and electroplating of metals, the benefits and harmful effects of electrolysis in industries.

The electrolysis instructional program

A summary of the instructional program that was conducted in the study over a period of six weeks in provided in Figure 1.

\section{Insert Figure 1 about here}

Formative assessment to ascertain students' understanding was incorporated during the course of instruction over the six weeks using mainly Socratic questioning techniques and by facilitating group discussions. Students' understanding of basic electrolysis concepts was assessed as summative assessment at the end of instruction in the topic using a diagnostic test (the EDI) described below. In addition, for each item in the EDI, students were also requested to suggest their level of confidence in arriving at their responses to the items on a Likert-type scale of 1 to 5 ranging from 'not at all confident' to 'totally confident'. 


\section{Development of the Electrolysis Diagnostic Instrument (EDI)}

Students' understanding of electrolysis concepts involving molten compounds and aqueous solutions of compounds was ascertained using the Electrolysis Diagnostic Instrument (EDI).

The development of the EDI first involved three major procedures to limit and specify the subject content related to electrolysis (Sia, 2010): (1) extraction of parts of the Malaysian School Certificate chemistry syllabus relevant to electrolysis referred to above, (2) formulating 41 propositional content knowledge statements about the electrolysis topic in the chemistry syllabus, and (3) development of a concept map to relate the propositional knowledge statements. Based on the propositional knowledge statements, 19 basic principles of electrolysis involving molten and aqueous solutions of compounds were identified (see Table 2). The literature was reviewed to determine students' knowledge and alternative conceptions in topics related to electrolysis. Subsequent stages in the development of the EDI are summarised in the flow diagram in Figure 2.

\section{Insert Figure 2 about here}

The EDI consisted of 17 two-tier multiple-choice items and was administered after students had completed a course of instruction on electrolysis based on the national chemistry curriculum. The first tier of the multiple-choice items solicited students' knowledge of particular electrolysis concepts; the second tier required students to select a reason for their choice of response to the first tier. An item was considered to be correctly answered if responses to both tiers were correct. Two examples of the two-tier multiple-choice items from the EDI are provided in Figure 3. The complete instrument with 17 items is available as online resource.

\section{Insert Figure 3 about here}




\section{Results and Discussion}

\section{Research question 1}

In response to research question 1 (How proficient are Form 4 (grade 10) students in understanding electrolysis concepts related to molten and aqueous solutions of compounds?), we decided that students' proficiency will be reflected in their overall test scores and in the extent to which they were able to explain their responses to the test items. This information was obtained by analysing students' responses using the SPSS software package (Version 17).

Students' overall test scores were computed based on the premise that the answer to an item was considered correct only when correct responses were provided to both tiers of the item. The frequency of the total scores achieved by the students is indicated in Figure 4. Only four students provided correct responses to both tiers in all 17 items in the diagnostic instrument, while one student was unable to answer any of the items correctly.

\section{Insert Figure 4 about here}

Additional statistical data obtained from the SPSS analysis are summarised in Figure 5.

\section{$\underline{\text { Insert Figure } 5 \text { about here }}$}

A Cronbach's alpha reliability analysis performed using the SPSS software program for the 330 cases and 17 items gave a coefficient of 0.85 which is greater than the threshold value of 0.5 quoted by Nunally and Bernstein (1994), suggesting that the 17 items provided a reliable evaluation of students' understanding of the electrolysis concepts concerned. 
It was also found that for all 17 items the percentage of students who correctly answered the first part was higher than the percentage who correctly answered both parts of the two-tier multiple-choice items (see Table 1). This tendency is an indication that students may have memorized certain facts relating to electrolysis without sufficient understanding of the concepts involved. A similar general tendency has been identified in several studies relating to the development of two-tier multiple-choice diagnostic instruments (e. g., Chandrasegaran, Treagust \& Mocerino, 2007; Tan, Treagust, Chandrasegaran \& Mocerino, 2010).

\section{Insert Table 1 about here}

The data indicate that the percentage of students who correctly answered the first-tier of the multiple-choice items ranged from $49 \%$ to $91 \%$. The percentage of students who answered both parts of the two-tier items correctly ranged from $19 \%$ to $79 \%$.

\section{Research question 2}

In response to research question 2 (How consistent are Form 4 (grade 10) students in displaying understanding of the basic principles related to the electrolysis of molten and aqueous solutions of compounds in different contexts?), students' consistency in understanding of a particular principle that was assessed by more than one item in the EDI was computed. With the exception of principles $1,8,12,13,14,16$ and 17 that were assessed by only one item each, understanding of all the other principles were assessed by two or more items. The list of the 19 basic principles of electrolysis of molten and aqueous compounds as well as consistency in students' understanding of the 12 principles is summarised in Table 2. 


\section{Insert Table 2 about here}

It is evident from the data in Table 3 that students generally displayed very limited understanding of electrolysis principles with less than $20 \%$ of students displaying consistent understanding of 10 out of the 12 principles that were assessed by more than one item. These principles involved understanding of the (1) anode and cathode in electrolytic cells, (2) ions present in a molten electrolyte, (3) ions present in an aqueous electrolyte, (4) direction of migration of ions in molten/aqueous electrolytes, (5) neutralisation of the ions at the electrodes in a molten electrolyte, (6) products at the electrodes when a molten compound is electrolysed, (7) products at the electrodes when a dilute aqueous solution of a compound is electrolysed using inert electrodes, (8) selective discharge of ions from aqueous solutions of compound during electrolysis, (9) changes in concentration of an aqueous solution of an electrolyte during electrolysis using inert electrodes, and (10) changes to an electrode during electrolysis.

A higher percentage of students (35\%) displayed consistent understanding about the (1) rust prevention of an object by electroplating with metals like nickel, silver and chromium, and (2) formation of a strongly-adhering coating on an electroplated object by electroplating metals like nickel, silver and chromium.

Even when a principle was assessed by just a single item (principles 1, 8, 12, 13, 14, 16 and 17) the percentage of students who displayed scientifically acceptable understandings of six of the seven the principles involved ranged from $19 \%-44 \%$. The only exception was the scientifically acceptable understanding of the differences between electrolytes and nonelectrolytes that was displayed by $79 \%$ of the students. 


\section{Research question 3}

In order to answer this research question (How confident are Form 4 (grade 10) students in responding to the 17 items in the EDI?) students were required to indicate their level of confidence in answering each of the items. They responded by making a selection on a Likert-type scale of 1 to 5 that ranged from 'not at all confident' to 'totally confident'.

In all items (except Item 1) the percentage of students who were confident that they had selected the correct answer to an item was higher than the actual percentage of students who correctly answered the corresponding item (see Table 3). This tendency may in part be attributed to students' general unfamiliarity with being asked to justify their choice of responses to multiple-choice items. These data are represented graphically in Figure 6.

\section{Insert Table 3 about here}

\section{Insert Figure 6 about here}

Students' confidence in arriving at the answers for items 4, 13 and 14 regarding the electrolysis of molten lead(II) bromide, manufacture of chlorine in industry and extraction of aluminium from molten aluminium oxide respectively, was lower than for the rest of the items. This tendency may be attributed to students' unfamiliarity with industrial applications of electrolysis that may not have been emphasised during instruction.

Students were more confident in arriving at the answers for the rest of the items probably as a result of several factors, like keeping up-to-date with their work and persistently trying out similar problems to achieve success. Chan and Mousley (2005) found that most of the students in their study felt "a need to practice sufficient examples before they developed adequate confidence and curiosity for more independent and diverse ways of 
solving problems" (p. 223). Another possible factor could be the encouraging and patient teachers who had always been generous with positive evaluative feedback that is essential for students to achieve better results. This type of positive evaluative feedback involving verbal persuasion is supported by Dalgety, Coll and Jones (2003) who found that during high school, students developed attitudes and efficacy beliefs toward chemistry that they carried with them to their tertiary-level studies. In the classroom, the students could have modelled the teachers' methods of arriving at the correct answers besides getting help from their friends (Bowen \& Roth, 1999).

\section{Conclusions and implications for instruction and research}

The findings of this study based on the three research questions that were formulated at the outset are summarised as follows:

Research question 1: How proficient are Form 4 (grade 10) students in understanding the concepts related to the electrolysis of molten and aqueous solutions of compounds?

With a mean score of 6.82 (out of a possible maximum of 17), the students displayed very limited understanding of the electrolytic processes involving molten compounds and aqueous solutions of compounds. There were indications that students possessed some content knowledge but lacked the ability to provide suitable explanations for the changes that occurred during the electrolytic processes.

Research question 2: How consistent are Form 4 (grade 10) students in displaying understanding of the basic principles related to the electrolysis of molten and aqueous solutions of compounds in different contexts?

A total of 19 major principles of electrolysis were identified in the 17 items of the EDI. Twelve of these principles were incorporated in two or more of the items, while seven of the principles were assessed by a single item each. Less than $20 \%$ of students displayed 
consistent understanding of 10 out of the 12 principles that were assessed by more than one item. For six of the seven principles that were assessed by a single item, only $19 \%-44 \%$ of students displayed scientifically acceptable understandings about electrolysis.

Research question 3: How confident are Form 4 (grade 10) students in responding to the 17 items in the diagnostic instrument?

In all items (except Item 1) the percentage of students who were confident that they had selected the correct answer to an item was higher than the actual percentage of students who correctly answered the corresponding item. This tendency may in part be attributed to students' general unfamiliarity with being asked to justify their choice of responses to multiple-choice items in their normal course of study.

It is vital for students to get access to correct sources of information in textbooks. Chiu (2007) found that for high school students, the teachers' instruction, textbooks, and teaching materials were the main sources of student conceptions in chemistry. Teachers should help select the teaching materials such as the appropriate use of models, illustrations, and definitions of new terminology to help students learn chemistry concepts more effectively.

The special language of chemistry poses problems to the learners (Boo, 1998; Fensham, 1994; Gabel, 1999). In classrooms, often no distinction is made between the scientific meaning and the commonplace meanings of vocabulary such as precipitation, energy, or bond (Boo, 1998; Fensham, 1994). Confusion and frustration arise when teachers and textbooks use everyday vocabulary in explanations of chemical phenomena assuming that students understand the chemical meanings of the terms being used (Nakhleh, 1994; Schmidt, 1997). Therefore careful choice of language is very important in the teaching of chemistry. As Andersson (1986) has stressed, lacking the appropriate framework, students may misinterpret the words of teachers and textbook authors giving rise to alternative 
conceptions. Treagust and Chittleborough (2001) also discussed the difficulties experienced by students in comprehending the specialised language used in chemistry and distinguishing it from the everyday meanings of identical or similar terms.

Students might find the reactions involved in electrolysis difficult to understand because they involve "abstract and formal explanations of invisible interactions between particles at a molecular level" (Carr, 1984, p. 97). Nakhleh and Krajcik (1994) explained that in order for a student to engage in chemical reasoning, the student may need to constantly shift between four representational systems, the macroscopic, submicroscopic, symbolic and algebraic, and this causes further difficulties. The use of multimedia animations could further facilitate the understanding of reactions at the submicroscopic level (Chiu \& $\mathrm{Wu}, 2009$; Sanger \& Greenbowe, 1997a; Yochum \& Luoma, 1995). A study performed by Sanger and Greenbowe (1997a) suggested that "using computer animations depicting chemical reactions on the molecular level and a teaching approach that confronted student misconceptions dramatically decreased the proportion of students consistently demonstrating that electrons can travel through aqueous solutions" (p. 396). The teaching software provided by the Curriculum Division of the Ministry of Education, Malaysia has a good selection of the animations necessary to help the students understand the chemical reactions at the submicroscopic level (or molecular level), such as the electrolysis of dilute sulphuric acid using carbon electrodes and the purification of copper metal using copper(II) sulphate solution. This study did not investigate the teaching strategies used by the teachers in the classrooms, and it was anticipated that the Form 4 (grade 10) chemistry teachers were able to guide their students to understand the electrolysis concepts at the submicroscopic level. Nevertheless, Treagust and Chittleborough (2001) cautioned that by "simply having access to computer software and multimedia is not enough to affect students learning and without teacher facilitation the resources may not be used to their full potential"' (p. 258). 
The extent of the application of the multimedia software recommended by the Curriculum Division of Malaysia to teach particular concepts of electrolysis and electrochemistry and the strategies of teachers in illustrating the concepts to the students may be of further interest. The use of animations has also been recommended by Sanger and Greenbowe (1997b) and Yochum and Luoma (1995) and has shown to have greatly improved students' understanding of the concepts demonstrated. 


\section{References}

Acar, B., \& Tarhan, L. (2007). Effect of cooperative learning strategies on students' understanding of concepts in electrochemistry. 5(2), 349-373.

Andersson, B. R. (1986). Pupils' explanations of some aspects of chemical reactions. Science Education, 70(5), 549-563.

Ausubel, D. P. (1968). Educational psychology: A cognitive view. New York: Holt, Rinehart and Winston.

Boo, H. K. (1998). Students' understanding of chemical bonds and the energetics of chemical reactions. Journal of Research in Science Teaching, 35(5), 569-581.

Bowen, G. M., \& Roth, W-M. (1999). Confidence in performance on science tests and student preparation strategies. Research in Science Education, 29(2), 209-226.

Carr, M. (1984). Model confusion in chemistry. Research in Science Education, 14, 97-103.

Chan, K. H., \& Mousley, J. (2005). Using word problems in Malaysian mathematics education: Looking beneath the surface. In H. L. Chick \& J. L. Vincent (Eds.), Proceedings of the 29th Conference of the International Group for the Psychology of Mathematics Education. (Vol. 2, pp. 217-224). Melbourne: PME.

Chandrasegaran, A. L., Treagust, D. F., \& Mocerino, M. (2007). The development of a twotier multiple-choice diagnostic instrument for evaluating secondary school students' ability to describe and explain chemical reactions using multiple levels of representation. Chemistry Education Research and Practice, 8(3), 293-307.

Chiu, M-H. (2007). A national survey of students' conceptions of chemistry in Taiwan. International Journal of Science Education, 29(4), 421-452. 
Chiu, M-H., \& Wu, H. K. (2009). The roles of multimedia in the teaching and learning of the triplet relationship in chemistry. In J. K. Gilbert \& D. Treagust (Eds.), Multiple representations in chemical education (pp. 251-283). Dordrecht: Springer.

Curriculum Development Division, Ministry of Education Malaysia (2008). Malaysian school certificate chemistry syllabus for 2008. Kuala Lumpur, Malaysia: Author.

Dalgety, J., \& Coll, R. K. (2006). Exploring first-year science students' chemistry selfefficacy. International Journal of Science and Mathematics Education, 4, 97-116.

Dalgety, J., Coll, R. K., \& Jones, A. (2003). Development of chemistry attitudes and experiences questionnaire (CAEQ). Journal of Research in Science Teaching, 40(7), 649-668.

De Jong, O., \& Treagust, D. F. (2002). The teaching ad learning of electrochemistry. . In Gilbert, J. G., De Jong, O., Justi, R. Treagust, D. F. \& van Driel, J. H. (Eds.). Chemical education: Towards research based practice (pp. 317-338). Dordrecht, The Netherlands: Kluwer

Duit, R. (2009). Students' and teachers' conceptions and science education. Retrieved August 13, 2009 from http://www.ipn.uni-kiel.de/aktuell/stcse/stcse.html.

Duit, R., \& Treagust, D.F. (1995). Students conceptions' and constructivist teaching approaches. In B.J. Fraser \& H.J. Walberg (Eds.), Improving science education (pp. 46-69). Chicago, Illinois: The National Society for the Study of Education.

Duit, R., \& Treagust, D. F. (1998). Learning in science - from behaviourism towards social constructivism and beyond. In B. J. Fraser \& K. G. Tobin (Eds.), International handbook of science education (Vol. 1, pp. 3-25). Dordrecht, The Netherlands: Kluwer Academic Publishers.

Duit, R., \& Treagust, D. F. (2003). Conceptual change: A powerful framework for improving science teaching and learning. Internal Journal of Science Teaching, 25(6), 671-688. 
Fensham, P. J. (1994). Beginning to teach chemistry. In P. J. Fensham, R. F. Gunstone \& R. T. White (Eds.), The content of science: A constructivist approach to its teaching and learning (pp. 14-28). London: Falmer Press.

Fraser, B. J., McRobbie, C. J., \& Giddings, G. J. (1993). Development and cross-national validation of a laboratory classroom environment instrument for senior high school. Science Education, 77(1), 1-24.

Gabel, D. L. (1999). Improving teaching and learning through chemistry education research: A look to the future. Journal of Chemical Education, 76(4), 548-554.

Garnett, P. J., \& Treagust, D. F. (1992a). Conceptual difficulties experienced by senior high school students of electrochemistry: Electric circuits and oxidationreduction equations. Journal of Research in Science Teaching, 29(2), 121-142.

Garnett, P. J., \& Treagust, D. F. (1992b). Conceptual difficulties experienced by senior high school students of electrochemistry: Electrochemical (galvanic) and electrolytic cells. Journal of Research in Science Teaching, 29(10), 1079-1099.

Harrison, A. G., \& Treagust, D. F. (1998). Modelling in science lessons: Are there better ways to learn with models? School Science and Mathematics, 98(8), 420-429.

Jack, B. M., Liu, C.-J., Chiu, H.-L., \& Tsai, C-Y. (2011). Measuring the confidence of 8th grade Taiwanese students' knowledge of acid and bases. International Journal of Science and Mathematics Education, Online First 18 May 2011.

Jung, W. (1993). Uses of cognitive science to science education. Science and Education, 2, $31-56$.

Lee, S.-J. (2007). Exploring students' understanding concerning batteries-Theories and practices. International Journal of Science Education, 29(4), 497-516.

Merriam, S. B. (1998). Qualitative research and case study applications in education. San Francisco, CA: Jossey-Bass Publishers. 
Nakhleh, M.B. (1994). Chemical education research in the laboratory environment. How can research uncover what students are learning? Journal of Chemical Education, 71(3), 201-205.

Nakhleh, M. B., \& Krajcik, J. S. (1994). Influence of levels of information as presented by different technologies on students' understanding of acid, base and $\mathrm{pH}$ concepts. Journal of Research in Science Teaching, 31(10), 1077-1096.

Nunally, J. C., \& Bernstein, I. H. (1994). Psychometric theory (3rd ed.). New York: McGraw-Hill.

Palmer, D. H. (2001). Factors contributing to attitude exchange amongst preservice elementary teachers. Science Education, 86(2), 122-138.

Pintrich, P.R., Marx, R.W., \& Boyle, R.A. (1993). Beyond cold conceptual change: The role of motivational beliefs and classroom contextual factors in the process of conceptual change. Review of Educational Research, 63, 167-199.

Sanger, M. J., \& Greenbowe, T. J. (1997a). Common student misconceptions in electrochemistry: galvanic, electrolytic, and concentration cells. Journal of Research in Science Teaching, 34(4), 377-398.

Sanger, M. J., \& Greenbowe, T. J. (1997b). Students' misconceptions in electrochemistry: Current flow in electrolyte solutions and the salt bridge. Journal of Chemical Education, 74, 819-823.

Schmidt, H. J. (1997). Students' misconceptions - looking for a pattern. Science Education, 81(2), 123-135.

Schmidt, H.-J., Marohn, A., \& Harrison, A. G. (2007). Factors that prevent learning in electrochemistry. Journal of Research in Science Teaching, 44(2), 258-283.

Sia, D. T. (2010). Development and Validation of a Two-tier Multiple-choice Diagnostic Instrument to Evaluate Secondary School Students' Understanding of Electrolysis 
Concepts and Comparing Students' Confidence in Answering the Items in the Instrument with Their Actual Performance in the Diagnostic Test. Unpublished $\mathrm{PhD}$ dissertation, Curtin University of Technology, Perth, Australia.

Tan, K. C. D., Treagust, D. F., Chandrasegaran, A. L., \& Mocerino, M. (2010). Kinetics of acid reactions: Making sense of associated concepts. Chemistry Education Research and Practice, 11(4), 267-280.

Treagust, D. F. (1995). Diagnostic assessment of students' science knowledge. In S. M. Glynn \& R. Duit (Eds.), Learning science in the schools: Research reforming practice (pp. 327-346). Mahwah, NJ: Lawrence Erlbaum Associates.

Treagust, D. F., \& Chandrasegaran, A. L. (2007). The Taiwan national science concept learning study in an international perspective. International Journal of Science Education, 29(4), 391-403.

Treagust, D. F., \& Chittleborough, G. (2001). Chemistry: A matter of understanding representations. Specific Instructional Methods and Activities, 8, 239-267. Bingley, UK: Emerald Group Publishing Limited.

Tytler, R. (2002). Teaching for understanding in science: Student conceptions research, and changing views of learning. Australian Science Teachers' Journal, 48(3), 14-21.

Yochum, S. M., \& Luoma, J. R. (1995). Augmenting a classical electrochemical demonstration. Journal of Chemical Education, 72(1), 55-56. 


\begin{tabular}{|c|c|}
\hline $\begin{array}{l}\text { Week } \\
\text { no. }\end{array}$ & Instructional outline \\
\hline 1 & $\begin{array}{l}\text { Electrolytes and non-electrolytes } \\
\text { Nature of particles: oppositely-charged ions (cations and anions) in } \\
\text { electrolytes and molecules in non-electrolytes. } \\
\text { Arrangement of particles in an electrolyte and a non-electrolyte. } \\
\text { Why different compounds can conduct electricity: dissociation of ionic } \\
\text { compounds into mobile ions in aqueous solutions; comparison with covalent } \\
\text { compounds. } \\
\text { Molten ionic compounds and aqueous solutions of ionic compounds as } \\
\text { examples of electrolytes. } \\
\text { Solutions of covalent compounds as non-electrolytes. } \\
\text { Practicals: To classify substances into electrolytes and non-electrolytes based } \\
\text { on the observation whether or not the bulb lights up in the electrical circuits. }\end{array}$ \\
\hline 2 & $\begin{array}{l}\text { Electrolysis of molten compounds } \\
\text { Definition of electrolysis. } \\
\text { An electrolytic cell. } \\
\text { Types and naming of electrodes as anode and cathode. } \\
\text { The process of electrolysis. } \\
\text { Practical demonstrations: To investigate the electrolysis of molten lead(II) } \\
\text { bromide and molten magnesium oxide. }\end{array}$ \\
\hline 3 & $\begin{array}{l}\text { Electrolysis of aqueous solutions and the electrochemical series } \\
\text { Anions and cations of a compound. } \\
\text { Products of electrolysis of selected aqueous solutions using platinum, carbon } \\
\text { and active metal electrodes (e.g., copper electrodes). } \\
\text { Selective discharge of ions at electrodes during electrolysis. } \\
\text { Writing half-equations for discharge of ions at the electrodes. } \\
\text { Practical: Electrolysis of dilute copper(II) sulfate solution using carbon } \\
\text { electrodes. } \\
\text { Practical: Electrolysis of dilute sulfuric acid using carbon electrodes. }\end{array}$ \\
\hline 4 & $\begin{array}{l}\text { Practical: To investigate the effect of the position of ions in the electrochemical } \\
\text { series on the products of electrolysis } \\
\text { Practical: To investigate the effect of the concentration of ions in hydrochloric } \\
\text { acid on the products of electrolysis using } 0.001 \mathrm{~mol} \mathrm{dm}^{-3} \text { and } 2 \mathrm{~mol} \mathrm{dm} \\
\text { hydrochloric acid } \\
\text { Practical: To investigate the effect of the types of electrodes on the products of } \\
\text { electrolysis using } 0.1 \mathrm{~mol} \mathrm{dm} \text {-3 copper(II) sulfate solution. }\end{array}$ \\
\hline $5 \& 6$ & $\begin{array}{l}\text { Electrolysis in industry } \\
\text { Extraction of metals - extraction of aluminium } \\
\text { Purification of metals } \\
\text { Practical: To study the purification of copper. } \\
\text { Electroplating of metals. } \\
\text { Practical: To study the electroplating of an iron spoon with copper. } \\
\text { The effects on the environment of the use of electrolysis in industry. }\end{array}$ \\
\hline
\end{tabular}

Figure 1 Outline of instruction program on electrolysis concepts 


\section{STUDY 1}

* Interview One

- 15 students from 5 classes in School Y

* Free response questions

- Solicited free response answers to 21 questions from the 15 students in School Y

* Developed first version of instrument consisting of 21

multiple-choice items with free response justifications

\section{STUDY 2}

* Refined first version of free response instrument to produce the second version

* Administered to 116 students from School X

\begin{tabular}{|l|}
\hline \multicolumn{1}{|c|}{ STUDY 3 } \\
*Interview Two \\
- 15 students from School X \\
*Developed first version of two-tier multiple- \\
choice instrument with 21 items \\
*Refinement of instrument
\end{tabular}

Figure 2 Flow diagram summarising Studies 1, 2, 3, and 4 


\section{Item 1}

In the two experiments below we would expect the bulb to light up only in Experiment 1.

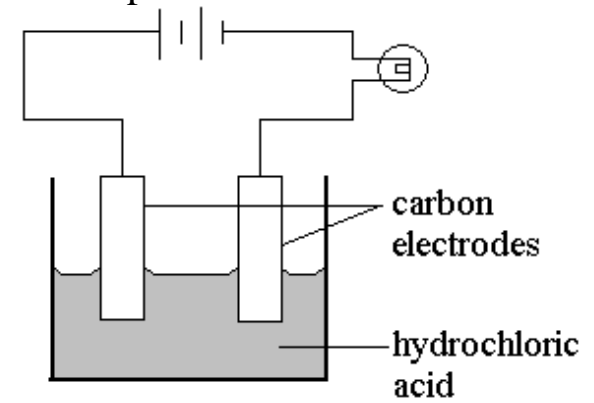

Experiment 1

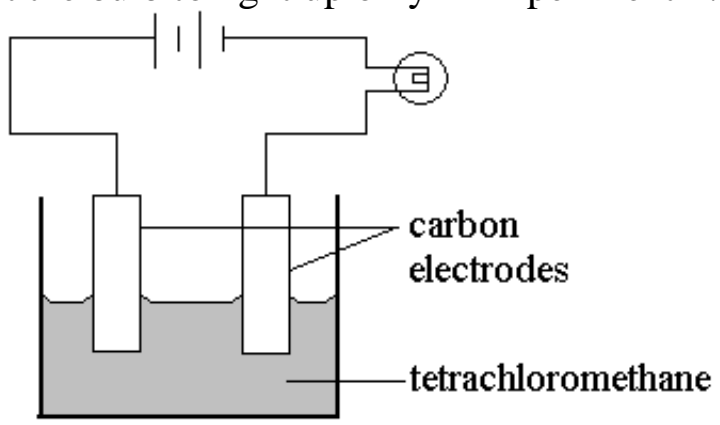

Experiment 2
A. True
B. False

The reason for my answer is:

1. Tetrachloromethane $\left(\mathrm{CCl}_{4}\right)$ contains more ions.

2. Tetrachloromethane $\left(\mathrm{CCl}_{4}\right)$ consists of free moving ions.

3. Hydrochloric acid $(\mathrm{HCl})$ consists of free moving ions.

4. The carbon anode dissolves producing ions.

\section{Item 14}

In the extraction of aluminium by the electrolysis of molten aluminium oxide using graphite electrodes, the graphite anode has to be periodically replaced.
A. True
B. False

The reason for my answer is:

1. The anode dissolves in the hot molten aluminium oxide.

2. The oxygen produced at high temperatures reacts with the anode.

3. The cathode dissolves in the hot molten aluminium oxide.

4. The chlorine produced at high temperatures oxidises the cathode.

Figure 3 Examples of two items from the Electrolysis Diagnostic Instrument 


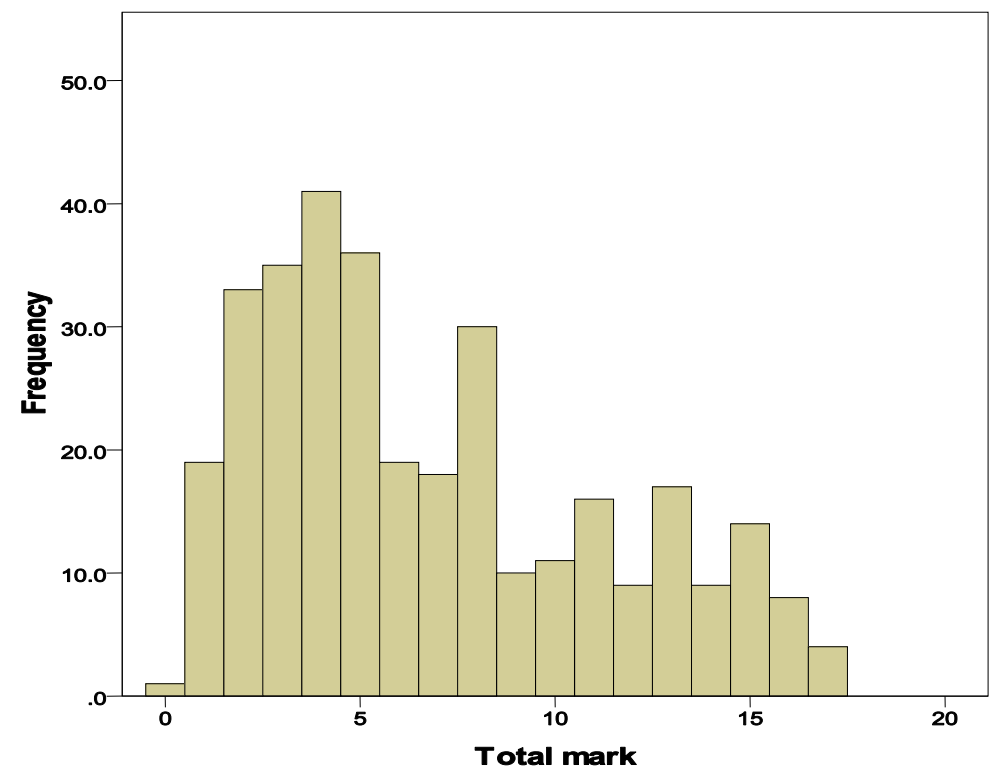

Figure 4 Frequency distribution of students' overall scores in the $E D I(\mathrm{~N}=330)$

\begin{tabular}{lc}
\hline Number of cases & 330 \\
Mean & 6.82 \\
Median & 5.50 \\
Standard deviation & 4.37 \\
Minimum & 0 \\
Maximum & 17 \\
\hline
\end{tabular}

Figure 5 Statistical data for student scores 


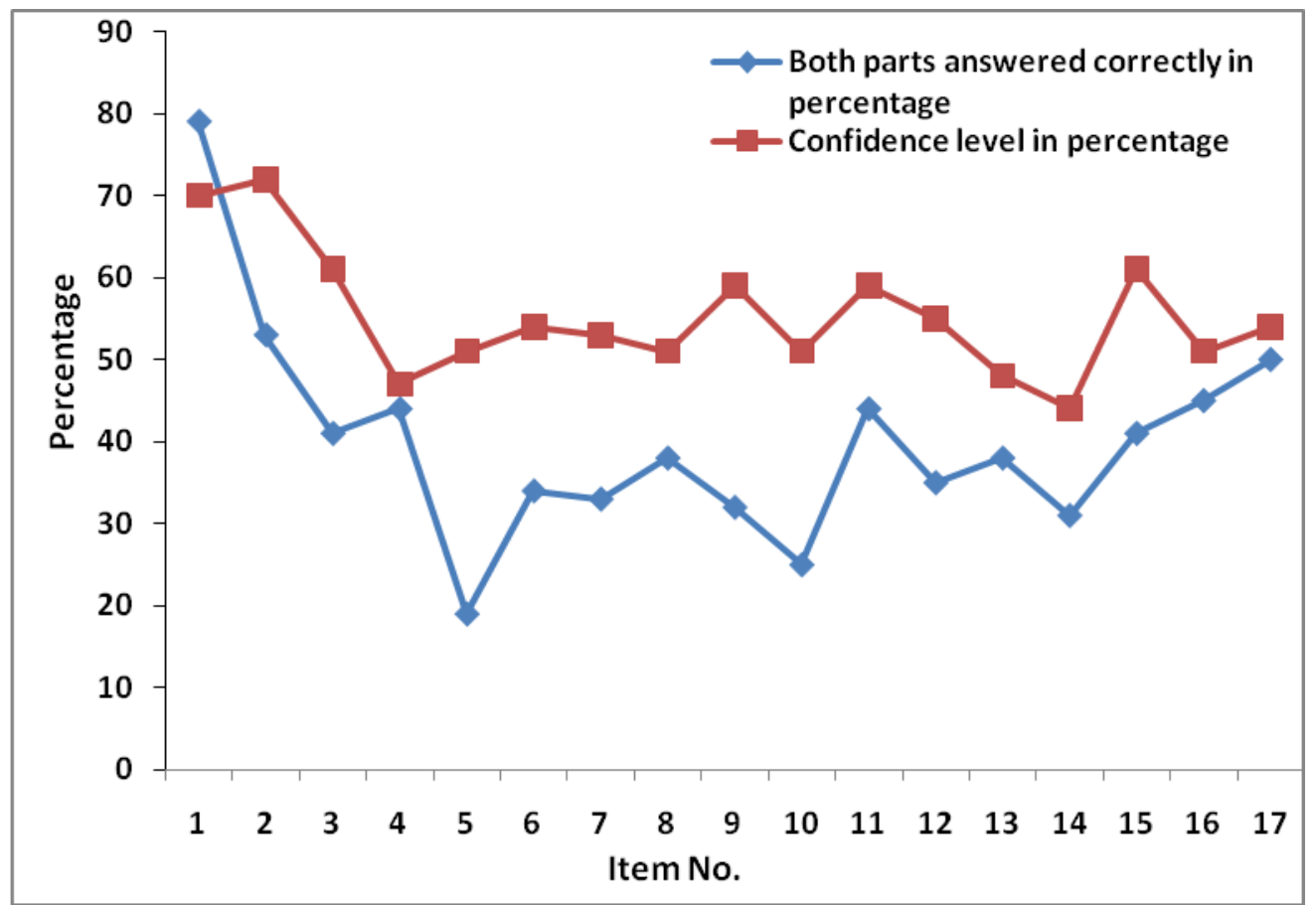

Figure 6 Graphs comparing students' confidence in answering the items in the EDI with their actual performance on the diagnostic test. 
Table 1 The percentage of students who correctly answered the first part and both parts of the items in the EDI $(\mathrm{N}=330)$

\begin{tabular}{|c|c|c|c|c|c|}
\hline \multirow{2}{*}{$\begin{array}{l}\text { Item } \\
\text { number }\end{array}$} & \multicolumn{2}{|c|}{$\begin{array}{l}\text { Percentage of students } \\
\text { who correctly answered }\end{array}$} & \multirow{2}{*}{$\begin{array}{c}\text { Item } \\
\text { number }\end{array}$} & \multicolumn{2}{|c|}{$\begin{array}{l}\text { Percentage of students } \\
\text { who correctly answered }\end{array}$} \\
\hline & First part & Both parts & & First part & Both parts \\
\hline 1 & 91 & 79 & 10 & 53 & 25 \\
\hline 2 & 86 & 53 & 11 & 61 & 44 \\
\hline 3 & 71 & 41 & 12 & 64 & 35 \\
\hline 4 & 70 & 44 & 13 & 62 & 38 \\
\hline 5 & 58 & 19 & 14 & 66 & 31 \\
\hline 6 & 61 & 34 & 15 & 68 & 41 \\
\hline 7 & 49 & 33 & 16 & 73 & 45 \\
\hline 8 & 62 & 38 & 17 & 76 & 50 \\
\hline 9 & 73 & 32 & & & \\
\hline
\end{tabular}


Table 2 Basic principles of electrolysis of molten and aqueous solutions of substances and students' consistency in understanding these principles $(\mathrm{N}=330)^{*}$

\begin{tabular}{|c|c|c|}
\hline No. & $\begin{array}{l}\text { Principles of electrolysis } \\
\text { (Items assessing the principles) }\end{array}$ & $\begin{array}{c}\text { Percentage of students } \\
\text { who answered all items } \\
\text { correctly (no. of } \\
\text { students) }\end{array}$ \\
\hline 1 & Differences between electrolytes and non-electrolytes (Item 1) & $79(260)$ \\
\hline 2 & $\begin{array}{l}\text { Anode and cathode in electrolytic cells (Items 2, 3, 4, 9, 10, 11, } 12 \text {, } \\
\text { and 14) }\end{array}$ & $6(19)$ \\
\hline 3 & Ions present in a molten electrolyte (Items 2, 3, 4 and 14) & $12(39)$ \\
\hline 4 & $\begin{array}{l}\text { Ions present in an aqueous electrolyte (Items 5, 6, 7, 8, 9, 10, 11, } 12 \\
\text { and 13) }\end{array}$ & $3(11)$ \\
\hline 5 & $\begin{array}{l}\text { Direction of migration of ions in molten/aqueous electrolyte } \\
\text { (Items } 2,3,4,9,10,11,12 \text { and } 14 \text { ) }\end{array}$ & $6(19)$ \\
\hline 6 & $\begin{array}{l}\text { Neutralisation of ions of molten electrolyte at the electrodes } \\
\text { (Items 2, } 3 \text { and 4) }\end{array}$ & $19(64)$ \\
\hline 7 & $\begin{array}{l}\text { Products at electrodes when a molten compound is electrolysed } \\
\text { (Items } 3,4,14 \text { and } 15)\end{array}$ & $11(35)$ \\
\hline 8 & $\begin{array}{l}\text { Changes in colour of aqueous solution of electrolyte during } \\
\text { electrolysis using inert electrodes (Item 5) }\end{array}$ & $19(64)$ \\
\hline 9 & $\begin{array}{l}\text { Products at electrodes when a dilute aqueous solution of a compound } \\
\text { is electrolysed using inert electrodes (Items 5, 6, } 10 \text { and 15) }\end{array}$ & $6(19)$ \\
\hline 10 & $\begin{array}{l}\text { Selective discharge of ions from aqueous solution of a compound } \\
\text { during electrolysis (Items } 5,6,7,10,11,12 \text { and13) }\end{array}$ & $5(16)$ \\
\hline 11 & $\begin{array}{l}\text { Changes in concentration of aqueous solution of electrolyte during } \\
\text { electrolysis using inert electrodes (Items } 5,7 \text { and } 8 \text { ) }\end{array}$ & $8(27)$ \\
\hline 12 & Nature of redox reaction at an electrode (Item 9) & $32(106)$ \\
\hline 13 & Choice of appropriate electrodes in electroplating (Item 11) & $44(145)$ \\
\hline 14 & Choice of appropriate electrodes in electro-refining (Item 12) & $35(116)$ \\
\hline 15 & Changes to an electrode during electrolysis (Items 8, 11, 12 and 14) & $13(44)$ \\
\hline 16 & $\begin{array}{l}\text { Products at electrodes when a concentrated aqueous solution of a } \\
\text { compound is electrolysed using inert electrodes (Item 13) }\end{array}$ & $38(126)$ \\
\hline 17 & $\begin{array}{l}\text { Waste products of electrolysis and effects on the environment } \\
\text { (Item 15) }\end{array}$ & $41(135)$ \\
\hline 18 & $\begin{array}{l}\text { Electroplating metals like nickel, silver and chromium prevent the } \\
\text { electroplated object from rusting (Items } 16 \text { and 17) }\end{array}$ & $35(108)$ \\
\hline 19 & $\begin{array}{l}\text { Electroplating metals like nickel, silver and chromium form a } \\
\text { strongly-adhering coating on the electroplated object } \\
\text { (Items } 16 \text { and 17) }\end{array}$ & $35(108)$ \\
\hline
\end{tabular}

NB: With the exception of principles $1,8,12,13,14,16$ and 17 that were assessed by only one item each, understanding of all the other principles was assessed by two or more items. 
Table 3 Students' confidence in answering each item in the $E D I(\mathrm{~N}=330)$

\begin{tabular}{ccc}
\hline $\begin{array}{c}\text { Item } \\
\text { no. }\end{array}$ & $\begin{array}{c}\text { Students who answered } \\
\text { both item tiers correctly } \\
(\%)\end{array}$ & $\begin{array}{c}\text { Students who were confident in } \\
\text { answering items }(\%)\end{array}$ \\
\hline 1 & 79 & 70 \\
2 & 53 & 72 \\
3 & 41 & 61 \\
4 & 44 & 47 \\
5 & 19 & 51 \\
6 & 34 & 54 \\
7 & 33 & 53 \\
8 & 38 & 51 \\
9 & 32 & 59 \\
10 & 25 & 51 \\
11 & 44 & 59 \\
12 & 35 & 55 \\
13 & 38 & 48 \\
14 & 31 & 44 \\
15 & 41 & 61 \\
16 & 45 & 51 \\
17 & 50 & 54 \\
\hline
\end{tabular}


Online Resource

\section{ELECTROLYSIS DIAGNOSTIC INSTRUMENT}

\section{Instructions to Students}

Answer all questions on the separate answer sheet provided

This paper consists of 17 items that evaluate your understanding of electrolysis.

Each question has two parts: a True-False response section followed by a multiplechoice reason.

For each item, you are asked to make one choice from the True-False response section and record your answer in the box provided.

Then choose one of the reasons from the multiple-choice reason section that best matches your answer to the first part of the item and record your answer in the second box.

\section{Remember it is important to select a reason}

Finally, record how confident you are in arriving at the answer for the item by writing a number in the third box using the scale below:

$\begin{array}{lllllll}\begin{array}{l}\text { Not at all } \\ \text { confident }\end{array} & 1 & 2 & 3 & 4 & 5 & \begin{array}{c}\text { Totally } \\ \text { confident }\end{array}\end{array}$

Do not forget to record your name and other details on your Answer Sheet

$$
\begin{gathered}
\text { Science and Mathematics Education Centre } \\
\text { Curtin University of Technology } \\
\text { Perth, WA. }
\end{gathered}
$$


ELECTROLYSIS DIAGNOSTIC INSTRUMENT ANSWER SHEET

Name:

Class:

Age:

years

Name of School:

Date:

1 Answer

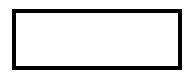

Reason

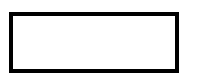

Confidence

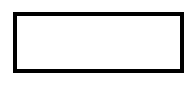

2
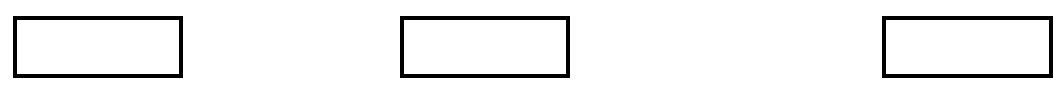

3
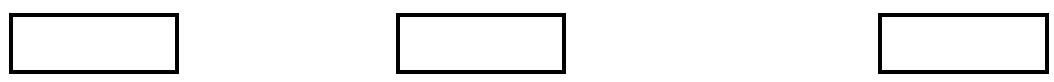

4
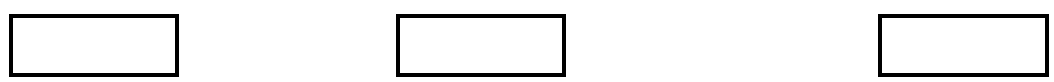

5
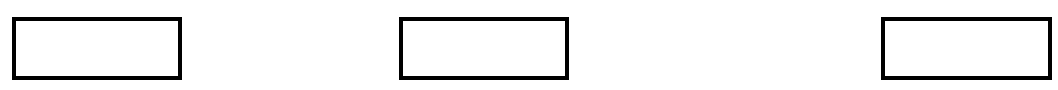

6
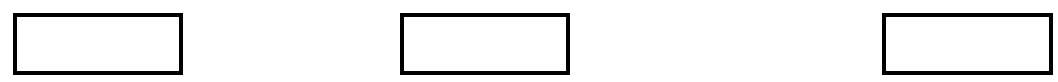

7
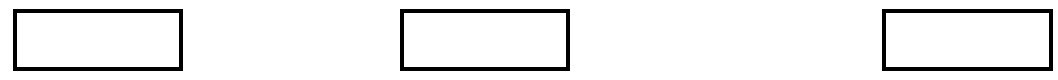

8
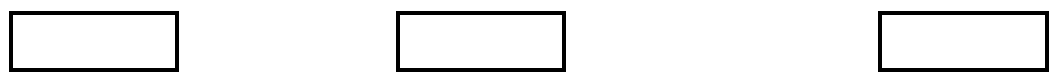

9
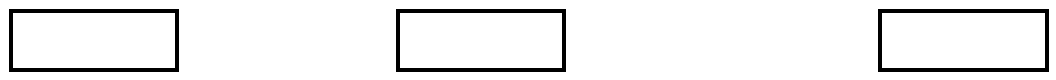

10
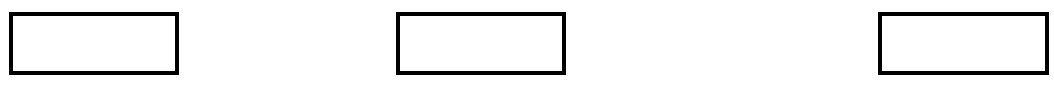

11
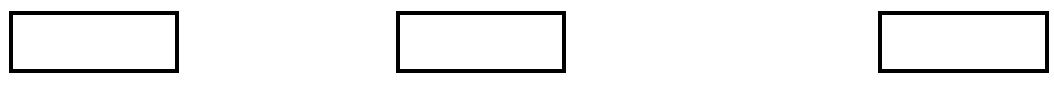

12
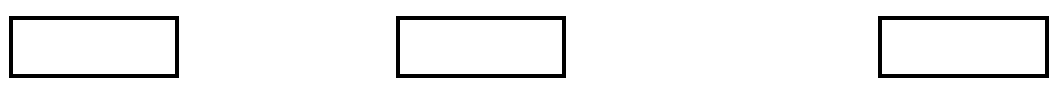

13
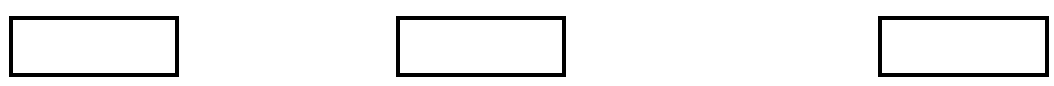

14
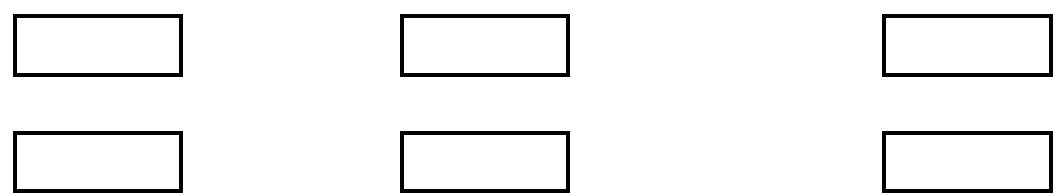

16
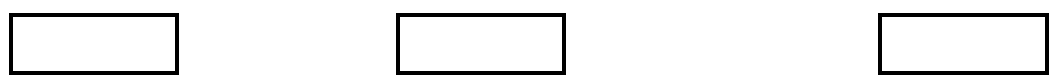

17
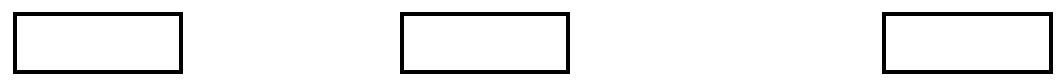


\section{Item 1}

\section{Electrolysis Diagnostic Instrument}

In the two experiments below we would expect the bulb to light up only in Experiment 1.

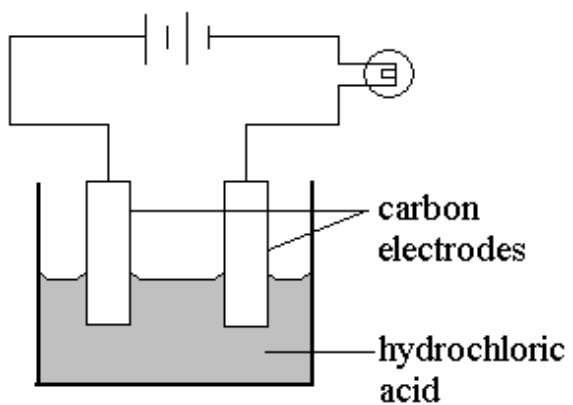

Experiment 1

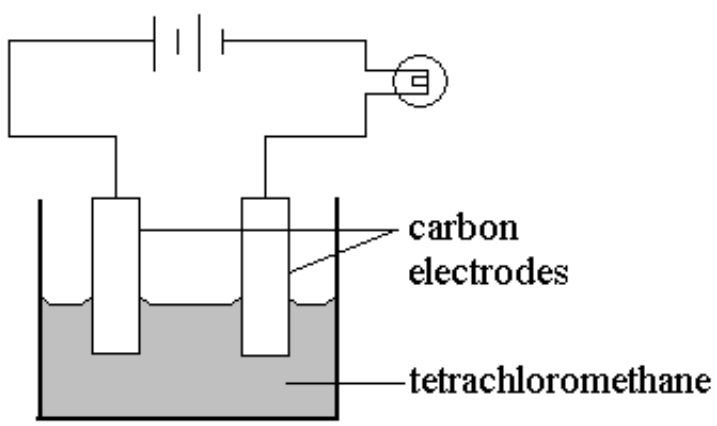

Experiment 2
A. True
B. False

The reason for my answer is:

1. Tetrachloromethane $\left(\mathrm{CCl}_{4}\right)$ contains more ions.

2. Tetrachloromethane $\left(\mathrm{CCl}_{4}\right)$ consists of free moving ions.

3. Hydrochloric acid $(\mathrm{HCl})$ consists of free moving ions.

4. The carbon anode dissolves producing ions.

\section{Item 2}

The diagram shows the electrolysis of molten magnesium oxide.

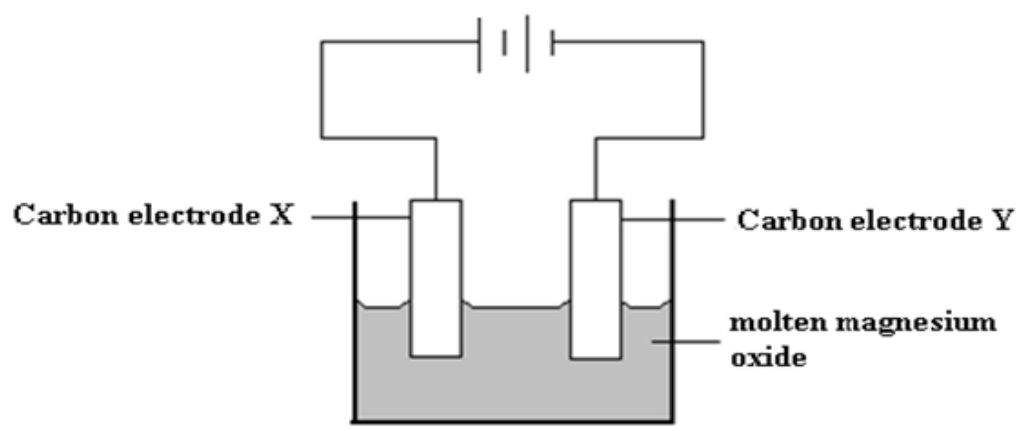

Electrode $\mathrm{X}$ is the anode.
A. True
B. False

The reason for my answer is:

1. Positive ions move to $\mathrm{X}$ and accept electrons.

2. Negative ions move to $X$ and donate electrons.

3. Positive ions move to $\mathrm{Y}$ and donate electrons.

4. Negative ions move to $\mathrm{Y}$ and accept electrons. 


\section{Item 3}

In the electrolysis of molten magnesium oxide using carbon electrodes, magnesium is produced at the anode.
A. True
B. False

The reason for my answer is:

1. Magnesium ions are attracted to the anode and accept electrons.

2. Magnesium ions are attracted to the cathode and donate electrons.

3. Magnesium ions are attracted to the anode and donate electrons.

4. Magnesium ions are attracted to the cathode and accept electrons.

\section{Item 4}

During electrolysis of molten lead(II) bromide using graphite electrodes, reddish fumes of bromine gas and molten lead are produced.
A. True
B. False

The reason for my answer is:

1. Bromide ions move to the cathode and are oxidised.

2. Bromide ions donate electrons at the anode and form bromine molecules.

3. Lead(II) ions are positively charged and so move to the anode.

4. Oxygen is attracted to the anode.

\section{Item 5}

When aqueous iron(II) sulfate is electrolysed using platinum electrodes, the light green colour of the solution becomes fainter.
A. True
B. False

The reason for my answer is:

1. Neither iron(II) ions nor sulfate ions are discharged, so the concentration of the solution remains unchanged.

2. Hydrogen ions and hydroxide ions are discharged, so the concentration of the solution remains unchanged.

3. Hydrogen ions and hydroxide ions are discharged, so the concentration of the solution increases.

4. The concentration of iron(II) ions decreases as iron is deposited at the cathode.

\section{Item 6}

The products of electrolysis of dilute sulfuric acid using inert electrodes are hydrogen at the cathode and oxygen at the anode.
A. True
B. False

The reason for my answer is:

1. Sulfate and hydrogen ions are selectively discharged.

2. Sulfate and hydroxide ions are selectively discharged.

3. The electrolyte consists of hydrogen ions and oxygen ions.

4. Hydrogen and hydroxide ions are selectively discharged.

5. No reaction occurs because platinum electrodes are inert. 


\section{Item 7}

When dilute sulfuric acid is electrolysed using inert electrodes, the concentration of the electrolyte increases.
A. True
B. False

The reason for my answer is:

1. Hydrogen and oxygen are selectively discharged, so the concentration of the acid decreases.

2. Hydrogen and sulfate ions are selectively discharged, so the concentration of the acid decreases.

3. Hydrogen and hydroxide ions are selectively discharged, so the concentration of the acid increases.

4. Hydrogen and hydroxide ions are selectively discharged, so the concentration of the acid remains the same.

\section{Item 8}

When aqueous copper(II) sulfate is electrolysed using platinum electrodes, a reddish-brown deposit is produced at the cathode. At the same time, the blue colour of the electrolyte remains unchanged.
A. True
B. False

The reason for my answer is:

1. Copper(II) ions are discharged and deposited at the cathode, so the colour of the electrolyte decreases in intensity.

2. Copper(II) ions are displaced by platinum, so the colour of the electrolyte decreases in intensity.

3. Platinum dissolves in the electrolyte, so the colour of the electrolyte increases in intensity.

4. Platinum electrodes are inert, so the colour of the electrolyte remains the same.

\section{Item 9}

The diagram below shows an electrolytic cell in which an electric current passes through a concentrated aqueous solution of copper(II) chloride using inert graphite electrodes.

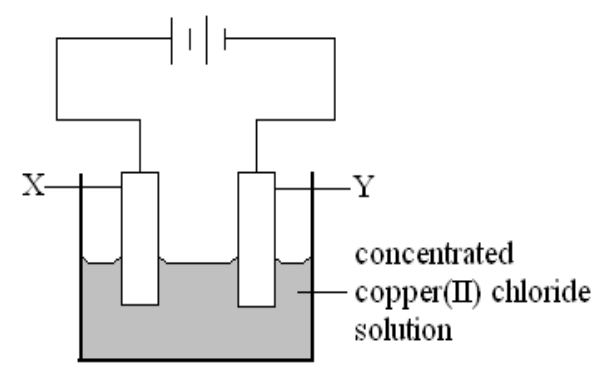

At electrode X, chloride ions are oxidised.
A. True
B. False 
The reason for my answer is:

1. Copper(II) ions move to $\mathrm{X}$ and accept electrons.

2. Copper(II) ions move to $\mathrm{X}$ and donate electrons.

3. Chloride ions move to $X$ and accept electrons.

4. Chloride ions move to $\mathrm{X}$ and donate electrons.

\section{Item 10}

When aqueous zinc nitrate is electrolysed using graphite electrodes, bubbles of gas are given off only at the cathode.
A. True
B. False

The reason for my answer is:

1. Hydrogen and hydroxide ions are selectively discharged over zinc and nitrate ions.

2. Hydrogen ions are discharged at the cathode, producing hydrogen gas.

3. Reaction occurs between zinc ions and the graphite electrodes.

4. Zinc is deposited at the cathode.

\section{Item 11}

In order to electroplate an iron spoon with silver using aqueous silver nitrate as electrolyte, the spoon should be used as the anode.
A. True
B. False

The reason for my answer is:

1. Silver ions are attracted to the anode and selectively discharged.

2. Silver ions are attracted to the cathode and selectively discharged.

3. Hydrogen ions are attracted to the cathode and selectively discharged.

4. Hydrogen ions are attracted to the anode and selectively discharged.

\section{Item 12}

In order to purify an impure copper plate using aqueous copper(II) sulphate, a pure copper plate must be used as the cathode.
A. True
B. False

The reason for my answer is:

1. Hydrogen ions are attracted to the cathode and selectively discharged.

2. Hydrogen ions are attracted to the anode and selectively discharged.

3. Copper(II) ions are attracted to the anode and selectively discharged.

4. Copper(II) ions are attracted to the cathode and selectively discharged. 


\section{Item 13}

In the manufacture of chlorine by electrolysis of concentrated aqueous sodium chloride using graphite electrodes, hydrogen gas is also produced.
A. True
B. False

The reason for my answer is:

1. Hydrogen ions are preferably discharged over hydroxide ions.

2. Hydrogen ions are selectively discharged over sodium ions.

3. Sodium chloride does not contain hydrogen ions.

4. The concentration of hydrogen ions is very low.

\section{Item 14}

In the extraction of aluminium by the electrolysis of molten aluminium oxide using graphite electrodes, the graphite anode has to be periodically replaced.
A. True
B. False

The reason for my answer is:

1. The anode dissolves in the hot molten aluminium oxide.

2. The oxygen produced at high temperatures reacts with the anode.

3. The cathode dissolves in the hot molten aluminium oxide.

4. The chlorine produced at high temperatures oxidises the cathode.

\section{Item 15}

The use of electrolysis in industry causes pollution of the environment.
A. True
B. False

The reason for my answer is:

1. Gases such as hydrogen and oxygen are released into the atmosphere.

2. Chemical wastes are released into the environment after proper treatment.

3. Heavy metal ions such as cadmium and nickel ions are released into water sources.

Items $\mathbf{1 6}$ and $\mathbf{1 7}$ are two examples in which electrolysis is used in industry for electroplating.

\section{Item 16}

In the motor industry, the metals nickel and chromium are used for electroplating.
A. True
B. False

The reason for my answer is:

1. The metals have high boiling and melting points.

2. The metals do not form a strongly adhering coating.

3. The metals prevent rusting.

4. The metals are chemically unreactive. 


\section{Item 17}

Cutlery items are often electroplated with silver and nickel.
A. True
B. False

The reason for my answer is:

1. Nickel reacts readily with silver.

2. Silver and nickel are expensive metals.

3. The cutlery becomes more brittle.

4. The cutlery becomes more resistant to corrosion.

Josephine Sia Ding Teng

Science \& Mathematics Education Centre

Curtin University of Technology

Perth, Australia

6 February 2012 